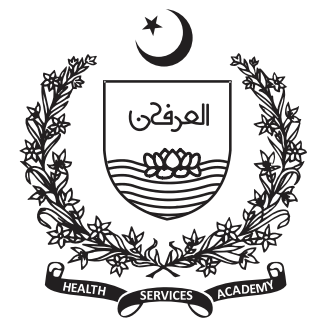

\title{
Retrospective Analysis of Periodontal Bone Loss from Orthopantogram X-Ray of Diabetic and Non-Diabetic Patients Visiting Punjab Dental Hospital Lahore
}

Faiz Rasul ${ }^{1}$, Amna Rizvi², Zainab Rizvi ${ }^{1}$, Sultan Muhammad Wahid", Muhammad Ammar', Saud Ahmed Cheema ${ }^{3}$

${ }^{1}$ de'Montmorency College of Dentistry Lahore

2Services Institutes of Medical Sciences Lahore

4Postgraduate medical institute/ Lahore General Hospital Lahore

Corresponding Author: Faiz Rasul

Email:

bayfaiz871@gmail.com

\section{Abstract}

Background: Periodontitis is a dental public health issue evident by interdental bone loss which can be detected by periapical and Orthopantograph (OPG) radiograph. The objective of this retrospective study was to compare bone loss in diabetic and non-diabetic patients visiting Punjab Dental Hospital (PDH) Lahore.

Methods: Bone loss was measured in mesial and distal sites of six teeth i.e. tooth numbers $16,11,26,31,36$, and 46 and a mean score was assigned to each tooth. A score $<2 \mathrm{~mm}$ was taken as normal and $>2 \mathrm{~mm}$ as bone loss from the cementoenamel junction (CEJ) to interdental bone (Alveolar bone crest). Data was entered into SPSS 22. Variables like age and bone loss were analyzed as mean and SD. A Chi-square test was applied between diabetic, non-diabetic, and independent variables. A p-value of equal to or less than 0.05 was taken as significant.

Results: This study included 101 OPG X-ray, 39 (38.6\%) diabetic and 62 (61.4) non-diabetics. The mean age in the diabetic group is $44.2821 \pm 6.1$ and in non-diabetic individuals it is $31.7581 \pm 9$.3. Bone loss in diabetics was as high as compared to non-diabetics. Such as in diabetics, tooth no.16's mean value is 3.8462 as compared to non-diabetics 2.7258. Significant association between bone loss and status of diabetes was observed in all teeth except tooth no. 31.

Conclusion: Radiographically, bone loss is more common in diabetic individuals than non-diabetic healthy people. First molars have more bone loss than incisors.

Keywords: Orthopantogram X-ray, periodontitis, interproximal bone loss, diabetes mellitus, retrospective analysis.

\section{Introduction}

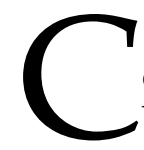

Periodontitis is a chronic inflammatory disease that begins with a buildup of dental biofilm plaque and continues through a disorganized immune response and is commonly started by gingivitis leading to irreversible demolition of the supportive tissues adjoining the tooth together with the alveolar bone. It is a multimicrobial and multifactorial disease with several risk factors such as plaque, smoking, diabetes mellitus and 
poor oral hygiene.(1) Diabetes Mellitus (DM) is a metabolic disorder characterized by high blood glucose levels resulting from altered insulin secretion, action or both.(2) Risk for periodontitis is increased two to three times more in diabetic individuals as compared to non-diabetics.(3) Recent meta-analysis suggested that there could be a common physiopathological factor between periodontitis and diabetes mellitus but more prospective studies are needed to investigate the association between these two diseases.(4)

Clinical and radiographic examinations play an important role in the evaluation and diagnosis of periodontal problems such as measurements of clinical attachment level and bone loss. (5) Radiograph provides vital information about the degree of bone loss, continuity, and integrity of the periodontal ligament space. Intraoral periapical (IOPA), Bitewing, and Orthopantomograms (OPG) radiographs are used to evaluate and diagnose bone loss in periodontitis. (6, 7)

OPG is a radiographic procedure that produces a single image of facial structures including maxilla mandible, and their supporting structures. It utilizes intensifying screens, requires less radiation, and saves time thereby making it a potential substitute for intraoral radiography in assessing periodontal conditions. (8) Digital panoramic radiograph is accepted as a method for measuring alveolar bone loss.(5) From OPG x-ray, periodontal diseases can be assessed because of certain radiographic characteristics like bone loss, widening of the periodontal ligament space, and decreased alveolar crest height. $(9,10)$ From OPG x-ray, early detection of periapical pathologies such as apical periodontitis, periapical cyst, granuloma, and other alterations in the morphological pattern of the alveolar and furcation involvement can be detected. Continuity of the lamina dura in radiographs is the visible and the earliest detectors of periapical pathologies. Any discontinuity or loss of the same can be detected in both conventional and digital imaging. (6) Detailed examination of OPG can give some incidental findings apart from periodontitis.(11) OPG is commonly used due to its several advantages for example: being easy and inexpensive to conduct, and informative regarding jaw morphology and bone density. $(12,13)$ The purpose of this retrospective study was to determine and compare bone loss (periodontitis) in diabetic and non-diabetic patients retrospectively from the OPG x-ray record of Punjab Dental Hospital. Another objective was to determine the difference in demographic characteristics in both subgroups in context to periodontitis.

\section{Methodology}

This study was presented in the Institutional Review Board of de'Montmorency College of Dentistry (DCD) by the principal investigator (FR). Permission was granted through letter no 279 dated 21/01/2021. Retrospective data of the OPG and the patients were taken from Punjab Dental Hospital (PDH) which is a teaching hospital attached with de'Montmorency College of Dentistry (DCD), a major public dental hospital of the Lahore population. Inclusion criteria of the study was diabetic and non-diabetic patients of age range 18 to 50years having complete information such as age, gender, and OPG x-ray from January 2020 to January 2021. However, patients above 50 years of age and below 18 years of age were excluded from the study along with another comorbidity of any systemic disease like known cases of ischemic heart disease, autoimmune diseases, hypertensive, and syndromic patients. Information of age, gender, diabetes was taken from the indoor register of the outpatient department (OPD) record and Medical Record number was noted. OPG records of these patients who had been advised an X-ray were reviewed and a total of 101 patients records met the criteria.

The principal investigator (FR) assessed the OPG $\mathrm{x}$ rays of 39 diabetic and 62 non-diabetic patients. Bone loss was measured in six indexed teeth, i.e. tooth number 16 (Maxillary right first molar), 11 (Maxillary right central incisor), 26 (maxillary left first molar), 31 (mandibular left central incisor), 36 (mandibular left first molar), and 46 (mandibular right first molar) at mesial and distal sites of all six teeth and a mean score was assigned to each tooth of the patient with the help of an illuminator and a millimeter-scale from the cementoenamel junction to interdental bone (Alveolar bone crest) as narrated by Amaranath et al 2020.(14) Score $<2 \mathrm{~mm}$ was taken as normal and above was considered as a confirmation of the presence of periodontal bone loss. Data was entered into SPSS 22. Variables like age and bone loss were analyzed as mean and SD. Frequencies and percentages of variables like gender, residence, socioeconomic position, diabetic and non-diabetic were calculated. A Chi-square test was applied between diabetic and non- 
Retrospective Analysis of Periodontal Bone Loss from Orthopantogram X-Ray of Diabetic and Non-Diabetic Patients Visiting Punjab Dental Hospital Lahore

diabetic variables and independent variables. Pvalue of equal to or less than 0.05 was taken as significant.

\section{Results}

The mean age in the diabetic group is $44.2821 \pm 6.1$ and $31.7581 \pm 9.3$ in non-diabetic individuals. Females are more in number $69(68.31 \%)$ as compared to males 32 $(31.69 \%)$. Most of the people $64(63.4 \%)$ have family income < 20000 Pakistani Rupees. Majorities of them were non-diabetic $34(61.4 \%)$ as compared to diabetics $30(38.6 \%)$. Around 80 individuals have $<10$ years education out of which $52(65.0 \%)$ were non-diabetics and $28(35.0 \%)$ diabetics. Most of the people were partly skilled manual occupations 53 (52.5\%) out of which $28(52.8 \%)$ were diabetics and 25 were $(47.2 \%)$ non-diabetics (Table 1).

Table 1. Demographic Characteristics of diabetic and Non Diabetic Individuals $(\mathbf{n}=\mathbf{1 0 1})$

\begin{tabular}{|c|c|c|c|c|c|}
\hline $\begin{array}{l}\mathrm{Sr} \\
\text { No. }\end{array}$ & Variables & Subgroups & $\begin{array}{l}\text { Diabetics } \\
39 \\
(38.6 \%)\end{array}$ & $\begin{array}{l}\text { Non } \\
\text { Diabetics } \\
62(61.4 \%)\end{array}$ & $\begin{array}{l}\text { Total } \\
101(100 \%)\end{array}$ \\
\hline \multirow[t]{5}{*}{1} & \multirow[t]{5}{*}{ Age } & 18 to 40 years & $\begin{array}{l}11 \\
(18.0 \%)\end{array}$ & $\begin{array}{l}50 \\
(82.0 \%)\end{array}$ & $\begin{array}{l}61 \\
(100.0 \%)\end{array}$ \\
\hline & & 41 to 50 years & $\begin{array}{l}28 \\
(70.0 \%)\end{array}$ & $\begin{array}{l}12 \\
(30.0 \%)\end{array}$ & $\begin{array}{l}40 \\
(100.0 \%)\end{array}$ \\
\hline & & Total & $\begin{array}{l}39 \\
(38.6 \%)\end{array}$ & $\begin{array}{l}62 \\
(61.4 \%)\end{array}$ & $\begin{array}{l}101 \\
(100.0 \%)\end{array}$ \\
\hline & & Mean & 44.2821 & 31.7581 & 36.5941 \\
\hline & & Std. Deviation & 6.18125 & 9.33824 & 10.25980 \\
\hline \multirow[t]{3}{*}{2} & \multirow[t]{3}{*}{ Gender } & Male & $\begin{array}{l}9 \\
(28.1 \%)\end{array}$ & $\begin{array}{l}23 \\
(71.9 \%)\end{array}$ & $32(100.0 \%)$ \\
\hline & & Female & $\begin{array}{l}30 \\
(43.5 \%)\end{array}$ & $\begin{array}{l}39 \\
(56.5 \%)\end{array}$ & $\begin{array}{l}69 \\
(100.0 \%)\end{array}$ \\
\hline & & Total & $\begin{array}{l}39 \\
(38.6 \%)\end{array}$ & $62(61.4 \%)$ & $\begin{array}{l}101 \\
(100.0 \%)\end{array}$ \\
\hline \multirow[t]{4}{*}{3} & \multirow[t]{4}{*}{$\begin{array}{l}\text { Family } \\
\text { Income }\end{array}$} & $\begin{array}{l}<\quad 20000 \\
\text { Pakistani } \\
\text { Rupees }\end{array}$ & $\begin{array}{l}30 \\
(38.6 \%)\end{array}$ & $\begin{array}{l}34 \\
(61.4 \%)\end{array}$ & $\begin{array}{l}64 \\
(100.0 \%)\end{array}$ \\
\hline & & $\begin{array}{l}>20000 \quad \& \\
<50000 \\
\text { Pakistani } \\
\text { Rupees }\end{array}$ & $\begin{array}{l}5 \\
(22.7 \%)\end{array}$ & $\begin{array}{l}17 \\
(77.3 \%)\end{array}$ & $\begin{array}{l}22 \\
(100.0 \%)\end{array}$ \\
\hline & & \begin{tabular}{|l|}
$>50000$ \\
Pakistani \\
Rupees \\
\end{tabular} & $\begin{array}{l}4 \\
(26.7 \%)\end{array}$ & $\begin{array}{l}11 \\
(73.3 \%)\end{array}$ & $\begin{array}{l}15 \\
(100.0 \%)\end{array}$ \\
\hline & & Total & $\begin{array}{l}39 \\
(38.6 \%)\end{array}$ & $\begin{array}{l}62 \\
(61.4 \%)\end{array}$ & $\begin{array}{l}101 \\
(100.0 \%)\end{array}$ \\
\hline \multirow[t]{3}{*}{4} & \multirow[t]{3}{*}{ Education } & $\begin{array}{l}<10 \text { year } \\
\text { education }\end{array}$ & $\begin{array}{l}28 \\
(35.0 \%)\end{array}$ & $\begin{array}{l}52 \\
(65.0 \%)\end{array}$ & $\begin{array}{l}80 \\
(100.0 \%) \\
\end{array}$ \\
\hline & & $\begin{array}{l}>10 \text { year } \\
\text { education }\end{array}$ & $\begin{array}{l}11 \\
(52.4 \%)\end{array}$ & $\begin{array}{l}10 \\
(47.6 \%)\end{array}$ & $\begin{array}{l}21 \\
(100.0 \%) \\
\end{array}$ \\
\hline & & Total & $\begin{array}{l}39 \\
(38.6 \%)\end{array}$ & $\begin{array}{l}62 \\
(61.4 \%)\end{array}$ & $\begin{array}{l}101 \\
(100.0 \%)\end{array}$ \\
\hline 5 & Residence & Urban & 28 & $52(65.0 \%)$ & $80(100.0 \%)$ \\
\hline
\end{tabular}

\begin{tabular}{|c|c|c|c|c|c|}
\hline & & & $(35.0 \%)$ & & \\
\hline & & Rural & $\begin{array}{l}11 \\
(52.4 \%)\end{array}$ & $\begin{array}{l}10 \\
(47.6 \%)\end{array}$ & $\begin{array}{l}21 \\
(100.0 \%)\end{array}$ \\
\hline & & Total & $\begin{array}{l}39 \\
(38.6 \%)\end{array}$ & $\begin{array}{l}62 \\
(61.4 \%)\end{array}$ & $\begin{array}{l}101 \\
(100.0 \%)\end{array}$ \\
\hline 6 & Occupation & Professional & $\begin{array}{l}3 \\
(60.0 \%)\end{array}$ & $2(40.0 \%)$ & $5(100.0 \%)$ \\
\hline & & $\begin{array}{l}\text { Managerial, } \\
\text { senior } \\
\text { clerical } \\
\end{array}$ & $\begin{array}{l}0 \\
(0.0 \%)\end{array}$ & $\begin{array}{l}3 \\
(100.0 \%)\end{array}$ & $3(100.0 \%)$ \\
\hline & & $\begin{array}{l}\text { skilled, non- } \\
\text { manual }\end{array}$ & $\begin{array}{l}8 \\
(23.5 \%)\end{array}$ & $\begin{array}{l}26 \\
(76.5 \%)\end{array}$ & $\begin{array}{l}34 \\
(100.0 \%)\end{array}$ \\
\hline & & $\begin{array}{l}\text { skilled, } \\
\text { manual }\end{array}$ & $\begin{array}{l}0 \\
(0.0 \%)\end{array}$ & $\begin{array}{l}6 \\
(100.0 \%) \\
\end{array}$ & $6(100.0 \%)$ \\
\hline & & $\begin{array}{l}\text { partly } \\
\text { skilled } \\
\text { manual } \\
\text { occupations }\end{array}$ & $\begin{array}{l}28 \\
(52.8 \%)\end{array}$ & $\begin{array}{l}25 \\
(47.2 \%)\end{array}$ & $\begin{array}{l}53 \\
(100.0 \%)\end{array}$ \\
\hline & & Total & $\begin{array}{l}39 \\
(38.6 \%)\end{array}$ & $\begin{array}{l}62 \\
(61.4 \%)\end{array}$ & $\begin{array}{l}101 \\
(100.0 \%)\end{array}$ \\
\hline
\end{tabular}

Table 2 describing the descriptive statistics in six teeth, tooth \#16 has maximum bone loss with a mean of 3.1584 out of 101 around $55.4 \%$ have periodontitis, and the remaining are considered as normal because bone loss is less than $2 \mathrm{~mm}$. Similarly, other molars 46 , 26 and 36 have mean bone loss of 2.6386, 2.7228 and 2.7198 and periodontitis $49.5 \%, 37.6 \%$ and $47.5 \%$ respectively. The mean value of bone loss in incisors is of normal range with only $18.8 \%$ and $20.8 \%$ periodontitis with more than $2 \mathrm{~mm}$ bone loss in 11 and 31 respectively.

Table 2. Descriptive statistics of Bone loss by Tooth Number

\begin{tabular}{|l|l|l|l|l|l|}
\hline $\begin{array}{l}\text { Toot } \\
\text { h \# }\end{array}$ & Mean & $\begin{array}{l}\text { Std. } \\
\text { Deviatio } \\
\mathbf{n}\end{array}$ & $\begin{array}{l}<\mathbf{2} \mathbf{m m} \\
\text { (Bone loss) }\end{array}$ & $\begin{array}{l}>\text { 2 mm (Bone } \\
\text { loss) }\end{array}$ & Total \\
\hline 16 & 3.1584 & 1.86940 & $45(44.6 \%)$ & $56(55.4 \%)$ & $101(100 \%)$ \\
\hline 46 & 2.6386 & 1.65547 & $51(50.5 \%)$ & $50(49.5 \%)$ & $101(100 \%)$ \\
\hline 11 & 1.6931 & 1.02706 & $81(81.2 \%)$ & $19(18.8 \%)$ & $101(100 \%)$ \\
\hline 31 & 1.6584 & 1.35818 & $80(79.2 \%)$ & $21(20.8 \%)$ & $101(100 \%)$ \\
\hline 26 & 2.7228 & 2.14997 & $63(62.4 \%)$ & $38(37.6 \%)$ & $101(100 \%)$ \\
\hline 36 & 2.7198 & 1.77612 & $53(52.5 \%)$ & $48(47.5 \%)$ & $101(100 \%)$ \\
\hline
\end{tabular}

Table 3 comparisons of two groups are given. In the diabetic group, bone loss is more in all six teeth such as tooth \#16 mean value is 3.8462 as compared to nondiabetic group 2.7258, tooth \# 26 mean value is 3.8462 as compared to non-diabetic group 2.0161, tooth \# 36 mean value is 3.1282 as compared to non-diabetic group 2.4629, and tooth \# 46 mean value is 3.4103 as compared to non-diabetic group 2.1532. While in incisors, bone loss in the diabetic and non-diabetic groups lies in the normal range. 
Table 3. Comparison of mean of Bone loss By Tooth Number and Diabetic Status

\begin{tabular}{|l|l|l|l|l|l|l|l|}
\hline \multicolumn{2}{|l|}{ Study Groups } & \multicolumn{3}{l|}{ Bone loss in Tooth } \\
\cline { 3 - 8 } \multicolumn{2}{|l|}{} & $\# 16$ & $\# 46$ & $\# 11$ & $\# 31$ & $\# 26$ & $\# 36$ \\
\hline $\begin{array}{l}\text { Diabetic } \\
(39)\end{array}$ & Mean & 3.8462 & 3.4103 & 2.0256 & 2.1282 & 3.8462 & 3.1282 \\
\cline { 2 - 7 } & Std. Deviation & 1.82870 & 1.72013 & 1.15820 & 1.55478 & 2.32026 & 1.74988 \\
\hline $\begin{array}{l}\text { Non } \\
\text { diabetics } \\
(62)\end{array}$ & Mean & 2.7258 & 2.1532 & 1.4839 & 1.3629 & 2.0161 & 2.4629 \\
\cline { 2 - 7 } & Std. Deviation & 1.77570 & 1.42458 & .88228 & 1.13502 & 1.70575 & 1.75791 \\
\hline \multirow{2}{*}{ Total (101) } & Mean & 3.1584 & 2.6386 & 1.6931 & 1.6584 & 2.7228 & 2.7198 \\
\cline { 2 - 8 } & Std. Deviation & 1.86940 & 1.65547 & 1.02706 & 1.35818 & 2.14997 & 1.77612 \\
\hline
\end{tabular}

Table 4 is depicting relationship of bone loss by tooth and diabetes mellitus. A total of 50 cases in tooth \# 46 have a bone loss of more than $2 \mathrm{~mm}$ out of which 31(62\%) were diabetic and $19(38 \%)$ were non-diabetics. In tooth \# 26, a total of 38 cases have a bone loss of more than $2 \mathrm{~mm}$ out of which $24(63.2 \%)$ and $14(36.8 \%)$ non-diabetics. In tooth \# 36, a total 48 cases have bone loss $>2 \mathrm{~mm}$ out of which $23(47.9 \%)$ were diabetics and $25(52.1 \%)$ were nondiabetics. In tooth \# 16, a total of 56 cases have periodontitis out of which 30 (53.6\%) were diabetics and 26 (46.4\%) non-diabetics. Incisors have a few cases of periodontitis 19 and 21 cases in tooth \# 11 and 31 respectively. A significant association was observed in all teeth except tooth \# 31.

Table 4. Bone Loss $>2 \mathrm{~mm}$ and $<2 \mathrm{~mm}$, by Tooth and Diabetes status

\begin{tabular}{|c|c|c|c|c|}
\hline \multirow[t]{2}{*}{ Variable } & \multicolumn{3}{|c|}{ Bone Loss in \# 46} & \multirow{2}{*}{$\begin{array}{l}\text { P Value } \\
0.001\end{array}$} \\
\hline & $<2 \mathrm{~mm}$ & $>2 \mathrm{~mm}$ & Total & \\
\hline Diabetic & $8(15.7 \%)$ & $31(62 \%)$ & $39(38.6 \%)$ & \\
\hline Non Diabetic & $43(84.3 \%)$ & $19(38 \%)$ & $62(61.4 \%)$ & \\
\hline Total & $51(100 \%)$ & $50(100 \%)$ & $101(100.0 \%)$ & \\
\hline \multicolumn{5}{|c|}{ Bone Loss in \# 26} \\
\hline & $<2 \mathrm{~mm}$ & $>2 \mathrm{~mm}$ & Total & \multirow[t]{4}{*}{0.001} \\
\hline Diabetic & $15(23.8 \%)$ & $24(63.2 \%)$ & $39(38.6 \%)$ & \\
\hline Non Diabetic & $48(76.2 \%)$ & $14(36.8 \%)$ & $62(61.4 \%)$ & \\
\hline Total & $63(100.0 \%)$ & $38(100.0 \%)$ & $101(100.0 \%)$ & \\
\hline \multicolumn{5}{|c|}{ Bone Loss in \# 36} \\
\hline & $<2 \mathrm{~mm}$ & $>2 \mathrm{~mm}$ & Total & \multirow[t]{4}{*}{0.05} \\
\hline Diabetic & $16(30.2 \%)$ & $23(47.9 \%)$ & $39(38.6 \%)$ & \\
\hline Non Diabetic & $37(69.8 \%)$ & $25(52.1 \%)$ & $62(61.4 \%)$ & \\
\hline Total & $53(100.0 \%)$ & $48(100.0 \%)$ & $101(100.0 \%)$ & \\
\hline \multicolumn{5}{|c|}{ Bone Loss in \# 16} \\
\hline & $<2 \mathrm{~mm}$ & $>2 \mathrm{~mm}$ & Total & \multirow[t]{4}{*}{0.001} \\
\hline Diabetic & $9(20.0 \%$ & $30(53.6 \%)$ & $39(38.6 \%)$ & \\
\hline Non Diabetic & $36(80.0 \%)$ & $26(46.4 \%)$ & $62(61.4 \%)$ & \\
\hline Total & $45(100.0 \%)$ & $56(100.0 \%)$ & $101(100.0 \%)$ & \\
\hline \multicolumn{5}{|c|}{ Bone Loss in \# 11} \\
\hline & $<2 \mathrm{~mm}$ & $>2 \mathrm{~mm}$ & Total & \multirow[t]{4}{*}{0.05} \\
\hline Diabetic & $28(34.1 \%)$ & $11(57.9 \%)$ & $39(38.6 \%)$ & \\
\hline Non Diabetic & $54(65.9 \%)$ & $8(42.1 \%)$ & $62(61.4 \%$ & \\
\hline Total & $82(100 \%)$ & $19(100 \%)$ & $101(100 \%)$ & \\
\hline \multicolumn{5}{|c|}{ Bone Loss in \# 31} \\
\hline & $<2 \mathrm{~mm}$ & $>2 \mathrm{~mm}$ & Total & \multirow[t]{4}{*}{0.115} \\
\hline Diabetic & $28(35.0 \%)$ & $11(52.4 \%)$ & $39(38.6 \%)$ & \\
\hline Non Diabetic & $52(65.0 \%)$ & $10(47.6 \%)$ & $62(61.4 \%$ & \\
\hline Total & $80(100.0)$ & $21(100.0 \%)$ & $101(100.0 \%)$ & \\
\hline
\end{tabular}


Retrospective Analysis of Periodontal Bone Loss from Orthopantogram X-Ray of Diabetic and Non-Diabetic Patients Visiting Punjab Dental Hospital Lahore

Table 5 is showing association between bone loss and age. Above 40 years of age, bone loss was observed in all teeth with the significant association except tooth \# 31 where $\mathrm{p}$-value is $>0.05$.

Table 5. Bone Loss $>2 \mathrm{~mm}$ and $<2 \mathrm{~mm}$, by Tooth and Age

\begin{tabular}{|c|c|c|c|c|}
\hline \multirow[t]{2}{*}{ Age } & \multicolumn{3}{|c|}{ Bone Loss in \# 46} & \\
\hline & $<2 \mathrm{~mm}$ & $>2 \mathrm{~mm}$ & Total & \multirow{4}{*}{0.001} \\
\hline $\begin{array}{l}18 \text { to } \\
40 \\
\text { year } \\
\text { age }\end{array}$ & $45(88.2 \%)$ & $16(32.0 \%)$ & $61(60.4 \%)$ & \\
\hline $\begin{array}{l}\text { Abov } \\
\text { e } 40\end{array}$ & $6(11.8 \%)$ & $34(68.0 \%$ & $40(39.6 \%)$ & \\
\hline Total & $51(100 \%)$ & $50(100 \%)$ & $\begin{array}{l}\text { 101(100.0 } \\
\%)\end{array}$ & \\
\hline \multicolumn{5}{|c|}{ Bone Loss in \# 26} \\
\hline & $<2 \mathrm{~mm}$ & $>2 \mathrm{~mm}$ & Total & \multirow{4}{*}{0.001} \\
\hline $\begin{array}{l}18 \text { to } \\
40 \\
\text { year } \\
\text { age }\end{array}$ & $50(79.4 \%)$ & $\begin{array}{l}11(28.9 \% \\
)\end{array}$ & $61(60.4 \%)$ & \\
\hline $\begin{array}{l}\text { Abov } \\
\text { e } 40\end{array}$ & $\begin{array}{l}13 \\
(20.6 \%\end{array}$ & $27(71.1 \%$ & $40(39.6 \%$ & \\
\hline Total & $\begin{array}{l}63 \\
(100.0 \%)\end{array}$ & $\begin{array}{l}38 \\
(100.0 \%)\end{array}$ & $\begin{array}{l}\text { 101(100.0 } \\
\%)\end{array}$ & \\
\hline \multicolumn{5}{|c|}{ Bone Loss in \# 36} \\
\hline & $<2 \mathrm{~mm}$ & $>2 \mathrm{~mm}$ & Total & \multirow[t]{4}{*}{0.004} \\
\hline $\begin{array}{l}18 \text { to } \\
40 \\
\text { year } \\
\text { age }\end{array}$ & $\begin{array}{l}39 \\
(73.6 \%)\end{array}$ & $\begin{array}{l}22(45.8 \% \\
)\end{array}$ & $61(60.4 \%)$ & \\
\hline $\begin{array}{l}\text { Abov } \\
\text { e } 40\end{array}$ & $\begin{array}{l}14 \\
(26.4 \%)\end{array}$ & $\begin{array}{l}26(54.2 \% \\
)\end{array}$ & $40(39.6 \%$ & \\
\hline Total & $\begin{array}{l}53(100.0 \\
\%)\end{array}$ & $\begin{array}{l}48(100.0 \\
\%)\end{array}$ & $\begin{array}{l}\text { 101(100.0 } \\
\%)\end{array}$ & \\
\hline \multicolumn{5}{|c|}{ Bone Loss in \# 16} \\
\hline & $<2 \mathrm{~mm}$ & $>2 \mathrm{~mm}$ & Total & \multirow{4}{*}{0.001} \\
\hline $\begin{array}{l}18 \text { to } \\
40 \\
\text { year } \\
\text { age }\end{array}$ & $36(80.0 \%$ & $\begin{array}{l}25(44.6 \% \\
)\end{array}$ & $61(60.4 \%)$ & \\
\hline $\begin{array}{l}\text { Abov } \\
\text { e } 40\end{array}$ & $9(20.0 \%)$ & $\begin{array}{l}31(55.4 \% \\
)\end{array}$ & $40(39.6 \%$ & \\
\hline Total & $\begin{array}{l}45(100.0 \\
\%)\end{array}$ & $\begin{array}{l}56(100.0 \\
\%)\end{array}$ & $\begin{array}{l}\text { 101(100.0 } \\
\%)\end{array}$ & \\
\hline
\end{tabular}

\begin{tabular}{|c|c|c|c|c|}
\hline & $<2 \mathrm{~mm}$ & $>2 \mathrm{~mm}$ & Total & \multirow{4}{*}{0.02} \\
\hline $\begin{array}{l}18 \text { to } \\
40 \\
\text { year } \\
\text { age }\end{array}$ & $54(65.9 \%)$ & $7(36.8 \%)$ & $61(60.4 \%)$ & \\
\hline $\begin{array}{l}\text { Abov } \\
\text { e } 40\end{array}$ & $28(34.1 \%)$ & $12(63.2 \%)$ & $40(39.6 \%$ & \\
\hline Total & $82(100 \%)$ & $19(100 \%)$ & $\begin{array}{l}101(100.0 \\
\%)\end{array}$ & \\
\hline \multicolumn{5}{|c|}{ Bone Loss in \# 31} \\
\hline & $<2 \mathrm{~mm}$ & $>2 \mathrm{~mm}$ & Total & \multirow{4}{*}{0.05} \\
\hline $\begin{array}{l}18 \text { to } \\
40 \\
\text { year } \\
\text { age }\end{array}$ & $52(65 \%)$ & $9(42.9 \%)$ & $61(60.4 \%)$ & \\
\hline $\begin{array}{l}\text { Abov } \\
\text { e } 40\end{array}$ & $28(35 \%)$ & $12(57.1 \%)$ & $40(39.6 \%$ & \\
\hline Total & $80(100 \%)$ & $21(100 \%)$ & $\begin{array}{l}\text { 101(100.0 } \\
\%)\end{array}$ & \\
\hline
\end{tabular}

\section{Discussion}

Bone loss is a radiological feature of periodontitis and the purpose of this study was to measure bone loss from OPG $x$-ray in diabetic and non-diabetic individuals. There is a controversy in the literature about the normal interdental space. Some says that it is less than $2 \mathrm{~mm}$, while others argue that it is less than $1.5 \mathrm{~mm}$.(15) We took $2 \mathrm{~mm}$ as normal space in the current study and observed bone loss of more than $2 \mathrm{~mm}$ in tooth \# 16 (55.4\%), \# 11 (18.8\%), \# 26 (37.6\%), \# 36 (47.5\%), \# 31 (20.8\%) and \# 46 (49.5\%). When these results were compared between diabetics and non-diabetics, bone loss (> $2 \mathrm{~mm})$ was observed more in people with diabetes as compared to non-diabetics in all selected teeth except tooth \# 31 and \# 36. One of the studies reported that people with diabetes have more periodontitis than prediabetics and healthy subgroups.(16)

Marginal bone loss on bitewing radiograph was more common in diabetics $4.7 \mathrm{~mm}$ and prediabetics $4.2 \mathrm{~mm}$ than in control healthy individuals $2.2 \mathrm{~mm}$. Furthermore, in the current study a maximum bone loss of $3.84 \mathrm{~mm}$ was observed in the diabetic group if mean is compared with the study of Alasqah et al., (2018).(17) In the diabetic group bone loss is more in all six teeth such as tooth \# 16 mean value is 3.8462 as compared to non-diabetic group 2.7258, tooth \# 26 mean value is 3.8462 as compared to non-diabetic group 2.0161, tooth \# 36 mean value is 3.1282 as 
compared to non-diabetic group 2.4629, and tooth \# 46 mean value is 3.4103 as compared to non-diabetic group 2.1532. Whereas in incisors, bone loss in the diabetic and non-diabetic groups lie within the normal range.

In another study Akram et al., reported a more marginal bone loss in poorly controlled diabetic individuals than in non-diabetic with periodontitis and healthy control group. Although in their study mean age group was higher than in the current study, where 55.2 years is in poorly controlled Diabetes with chronic periodontitis, 51.5 years in non-diabetic with periodontitis, and 50.7 years in healthy individuals with mean bone loss $5.2 \mathrm{~mm}, 4.1 \mathrm{~mm}$, and $1.6 \mathrm{~mm}$ in three groups respectively. (18) It is a known fact that patients with well-controlled diabetes mellitus have a periodontal status comparable to systemically healthy individuals.(19)

Plessas et al., 2018, concluded that DM participants had more radiographic alveolar bone loss throughout all the teeth measured and more than a two-fold increase in the risk of having sites with $\geq 2 \mathrm{~mm}$ periodontal destruction compared with non-diabetes subjects. (20) In 2017 Staging and grading of periodontitis was proposed by Tonetti et al., to ensure that the framework incorporates relevant new knowledge within an already functioning. The proposed risk stratification based on well-validated risk factors including smoking, uncontrolled diabetes, clinical evidence of progression or disease diagnosis at an early age, and severity of bone loss relative to patient age. (21)

Another important factor is given in a review by Poudel et al., that most diabetes care providers are not addressing oral health care due to time constraints and limited oral health awareness. Oral health awareness and referral to a dentist for routine visits play an important role which can be provided by diabetes educators (DEs). However, no appropriate oral health training programs and assessment tools exist for DEs. With proper training, non-dental professionals like nurses have successfully incorporated oral healthcare in other settings.(22) Similarly, oral health literacy to diabetic individuals is an important factor as health literacy gaps remain to be addressed in patient understanding the importance of detecting and managing dysglycemia for maintenance of periodontal health, creating opportunities for patient education.(23) Dentists who observe bone loss on $x$ ray examination, should refer the patient to the physician (diabetes care provider) for diabetes assessment or monitoring. So diagnosis and referral should work both ways; dentist to physician and physician to the dentist. (24)

Age is a risk factor in periodontitis; a study was conducted to determine age-dependent periodontitis in two populations of the United States and Germany in a large population with a sample size of 10713 and 3071respectively. Recession, periodontal pocket, and clinical attachment loss were taken as parameters to measure periodontitis. Mean clinical attachment loss increased linearly with age in both samples. (25) Mean age in this study is 36.59 (range 18 to 50 ) while in the diabetic group it is 44.28 and 31.75 in the non-diabetic group. Bone loss is also significantly associated with age however we categorized it into age less than 40 years and above 40 years. Due to poor matching of age in both groups bone loss was significantly associated in diabetic as well as in older age people.

In current study female gender is more common 69 $(68.31 \%)$ as compared to male $32(31.69 \%)$ which is contrary to the finding of Suphanantachat et al., (2017) in which 11 cases out of $14(78.5 \%)$ were male and 3 out of 14 (21.5\%) were female. (26) Akram et al., (2019) analyzed association of periodontitis with diabetes mellitus. In their study three groups were made: Group1 (diabetics with Periodontitis), Group 2 (nondiabetics with Periodontitis) and Group 3 (nondiabetics without Periodontitis). It was reported that male gender is more common as compared to female in all three groups that is 27 out of $32(84.37 \%), 25$ out of $31(80.64 \%), 27$ out of $31(87 \%)$ in group1, 2 and 3 respectively. (18)

High risk of Periodontitis is also associated with low socioeconomic status in current study and in Herrera et al., (2018). (27) Finding of a case and control study reported by Rafique et al., (2020) in Karachi shows that low education status is associated with Periodontitis that is similar to finding of the current study. (28)

In the current study bone loss was measured in OPG $\mathrm{x}$-ray while standard radiograph is periapical, and bitewing for measurement of bone loss however findings of bone loss can be comparable to bitewing. (29) Recently a scientific report was published by Krois et al., (2019) to measure bone loss by deep convolutional neural networks (CNNs) to detect periodontal bone loss (PBL) on panoramic dental radiographs. They also compared the results of CNNS to the findings of the senior dentist but did not find it superior in results but comparable with the advantage 
that machine-based technology can reduce the diagnostic efforts of the dentist. (30)

There are some limitations of the study. No numerical data was present to measure the glycemic level of the individuals; retrospectively, only we could find the status of diabetes, either it being present or absent. Secondly, we use OPG x-ray for detection of bone loss instead of bitewing or other advanced images to detect bone loss and exact matching of age could not be possible due to the availability of retrospective data however in comparison bone loss in all selected teeth is reported more in the diabetic population. Further prospective studies in local settings can be carried out by matching age in the case and control group and taking the value of blood glucose or $\mathrm{Hb} 1 \mathrm{Ac}$.

\section{Conclusion}

Interproximal bone loss, a pathognomonic sign of periodontitis, is more common in diabetics and older individuals than in non-diabetics and younger individuals. Maximum bone loss was observed in molars as compared to the incisors. In molars, mean bone loss was more than $3 \mathrm{~mm}$ in diabetics as compared to non-diabetics which have $2.1 \mathrm{~mm}$.

\section{Conflict of interest}

None of the authors has a conflict of interest or external funding

\section{Acknowledgment}

I am thankful to Dr. Jay Balzer, who is retired now from NYU Langone Health; New York, N. Y. USA, for helping in all aspects of our study from concept to writing and reviewing this study. I am also thankful to Dr. Safdar Baig, Associate Professor, Oral \& Dental Surgery, Quaid-e-Azam Medical College and Bahawal Victoria / Civil Hospital, Bahawalpur for his help in the analysis of the study.

\section{References}

1. AL-Haddad KA, Al-Najhi MM, Abbas AK, Al-Akwa AA, Al-Shamahy HA, Al-labani MA. Clinical features, age and sex distributions, risk factors and the type of bacteria isolated in periodontitis patients in Sana'a, Yemen. Universal Journal of Pharmaceutical Research. 2021;6(1):1-8.

2. Zheng M, Wang C, Ali A, Shih YA, Xie Q, Guo C. Prevalence of periodontitis in people clinically diagnosed with diabetes mellitus: a meta-analysis of epidemiologic studies. Acta Diabetologica. 2021 May 24:1-21.

3. Preshaw PM, Bissett SM. Periodontitis and diabetes. British dental journal. 2019 Oct;227(7):577-84.
4. Perez-Losada FD, Estrugo-Devesa A, CastellanosCosano L, Segura-Egea JJ, López-López J, VelascoOrtega E. Apical periodontitis and diabetes mellitus type 2: A systematic review and meta-analysis. Journal of clinical medicine. 2020 Feb;9(2):540.

5. Najm AA, Akram HM, Mahdi AS, Ali OH. Clinical and Radiographical Assessment of Alveolar Bone Loss Associated with Overhang Amalgam Filling. Health Sciences. 2018 Jan 1;7(1):11-6.

6. Kabilan A, Ganapathy D, Jain AR. Role of cone beam computed tomography in periodontics-A review.

7. Ogenyi PA, Halidu B, England A, Hayre C, Aliyu Y, Dlama JZ, Luntsi G. Appraisal of dental X-ray requests and findings in a northern Nigeria healthcare facility. The South African Radiographer. 2017 Dec 4;55(2):13-7.

8. Sairam V, Puri G. Comparison of measurements of alveolar bone levels by clinical, bitewing and panoramic radiography. Journal of Indian Academy of Oral Medicine and Radiology. 2011 Oct 1;23(4):543.

9. Hammadi ds, younis an, ramo fm. Hybridization and modification of the pso algorithm and its use in personal recognition by opg x-ray. Journal of Engineering Science and Technology. 2021 Feb;16(1):325-38.

10. Cederhag J, Lundegren N, Alstergren P, Shi XQ, HellénHalme K. Evaluation of Panoramic Radiographs in Relation to the Mandibular Third Molar and to Incidental Findings in an Adult Population. European journal of dentistry. 2020.

11. Caballero AD, Arenas $\mathrm{YH}$, Acosta SM. Inter-examiner concordance in the assessment of periodontal findings by means of panoramic X-rays. Revista odontológica mexicana. 2017 Apr 1;21(2):e97-100.

12. Semenoff L, Semenoff TDV, Pedro F,nVolpato L, Machado M, Borges A, et al. Are panoramic radiographs reliable to diagnose mild alveolar bone resorption? ISRN Dentistry. 2011;2011:363578. DOI:10.5402/2011/363578

13. Tang Z, Liu $X$, Chen $K$. Comparison of digital panoramic radiography versus cone beam computerized tomography for measuring alveolar bone. Head \& face medicine. 2017 Dec;13(1):1-7.

14. Amaranath BJ, Das N, Gupta I, Gupta R, John B, Devi MP. Types of bone destruction and its severity in chronic periodontitis patients with tobacco smoking habit using periapical radiographs and transgingival probing: A cross-sectional study. Journal of Indian Society of Periodontology. 2020 Jan;24(1):20.

15. Heikkinen AM, Esmaeili EP, Kovanen L, Ruokonen H, Kettunen K, Haukka J, Tervahartiala T, Sorsa T. Periodontal initial radiological findings of genetically predisposed finnish adolescents. Journal of clinical and diagnostic research: JCDR. 2017 Jul;11(7):ZC25.

16. Javed F, Thafeed AlGhamdi AS, Mikami T, Mehmood A, Ahmed HB, Samaranayake LP, Tenenbaum HC. Effect of glycemic control on self-perceived oral health, 
periodontal parameters, and alveolar bone loss among patients with prediabetes. Journal of periodontology. 2014 Feb;85(2):234-41.

17. Alasqah M, Mokeem S, Alrahlah A, Al-Hamoudi N, Abduljabbar T, Akram Z, Vohra F, Javed F. Periodontal parameters in prediabetes, type 2 diabetes mellitus, and non-diabetic patients. Brazilian oral research. 2018;32.

18. Akram Z,Alqahtani F, Alqahtani M, Al-Kheraif AA, Javed $F$. Levels of advanced glycation end products in gingival crevicular fluid of chronic periodontitis patients with and without type- 2 diabetes mellitus. $J$ Periodontol. 2019;1-7.

19. Javed F, Nasstrom K, Benchimol D, Altamash M, Klinge $\mathrm{B}, \mathrm{nEngstrom} \mathrm{PE}$. Comparison of periodontal and socioeconomic status between subjects with type 2 diabetes mellitus and non-diabetic controls. J Periodontol. 2007;78:2112-2119

20. Plessas A, Robertson DP, Hodge PJ. Radiographic bone loss in a Scottish non-smoking type 1 diabetes mellitus population: A bitewing radiographic study. Journal of periodontology. 2018 Sep;89(9):1043-51.

21. Tonetti MS, Greenwell H, Kornman KS. Staging and grading of periodontitis: Framework and proposal of a new classification and case definition. Journal of periodontology. 2018 Jun;89:S159-72

22. Poudel P, Griffiths R, Wong VW, Arora A, George A. Knowledge and practices of diabetes care providers in oral health care and their potential role in oral health promotion: a scoping review. Diabetes research and clinical practice. 2017 Aug 1;130:266-77.

23. Shimpi N, Glurich I, Schroeder D, Katrak C, Chyou PH, Acharya A. Patient Awareness of Association of Diabetes and Periodontal Disease. Health promotion practice. 2020 May;21(3):464-72.
24. Holmstrup P, Damgaard C, Olsen I, Klinge B, Flyvbjerg A, Nielsen $\mathrm{CH}$, Hansen PR. Comorbidity of periodontal disease: two sides of the same coin? An introduction for the clinician. Journal of oral microbiology. 2017 Jan 1;9(1):1332710.

25. Billings M, Holtfreter B, Papapanou PN, Mitnik GL, Kocher T, Dye BA. Age-dependent distribution of periodontitis in two countries: Findings from NHANES 2009 to 2014 and SHIP-TREND 2008 to 2012. Journal of clinical periodontology. 2018 Jun;45:S130-48.

26. Suphanantachat S, Tantikul K, Tamsailom S, Kosalagood P, Nisapakultorn K, Tavedhikul K. Comparison of clinical values between cone beam computed tomography and conventional intraoral radiography in periodontal and infrabony defect assessment. Dentomaxillofacial Radiology. 2017 Aug;46(6):20160461.

27. Herrera D, Meyle J, Renvert S, Jin L. White paper on prevention and management of periodontal diseases for oral health and general health. FDI World Dental Federation. 2018.

28. Rafique S, Khan S, Ahmed S, Qureshi MA, Amin R. Case-control study for assessment of factors associated with periodontitis among adults attending university hospital in Karachi, Pakistan. Journal of the Pakistan Medical Association. 2020 Sep 24:1-4.

29. Sairam V, Puri G. Comparison of measurements of alveolar bone levels by clinical, bitewing and panoramic radiography. Journal of Indian Academy of Oral Medicine and Radiology. 2011 Oct 1;23(4):543.

30. Krois J, Ekert T, Meinhold L, Golla T, Kharbot B, Wittemeier A, Dörfer C, Schwendicke F. Deep learning for the radiographic detection of periodontal bone loss. Scientific reports. 2019 Jun 11;9(1):1-6. 